6. Qu J, Zhang D, Zhang H, Rao C, Chen S, Zhao Y, et al. Preoperative clopidogrel and outcomes in patients with acute coronary syndrome undergoing coronary artery bypass surgery. J Thorac Cardiovasc Surg. 2022;163:1044-52.e15.

7. Mehran R, Rao SV, Bhatt DL, Gibson CM, Caixeta A, Eikelboom J, et al. Standardized bleeding definitions for cardiovascular clinical trials: a consensus report from the bleeding academic research consortium. Circulation. 2011; $123: 2736-47$.

8. Rydz N, James PD. The evolution and value of bleeding assessment tools. $J$ Thromb Haemost. 2012;23:2223-9.

9. Vuylsteke A, Pagel C, Gerrard C, Reddy B, Nashef S, Aldam P, et al. The Papworth bleeding risk score: a stratification scheme for identifying cardiac surgery patients at risk of excessive early postoperative bleeding. Eur $J$ Cardio-thoracic Surg. 2011;39:924-30.

10. Krishna NM, Nagaraja P, Singh NG, Nanjappa SN, Kumar KN, Prabhakar V, et al. Evaluation of risk scores in predicting perioperative blood transfusions in adult cardiac surgery. Ann Card Anaesth. 2019;22:73-8.

11. Hiteshi AK, Li D, Gao Y, Chen A, Flores F, Mao SS, et al. Gender differences in coronary artery diameter are not related to body habitus or left ventricular mass. Clin Cardiol. 2014;37:605-9.

12. Alghamdi AA, Davis A, Brister S, Corey P, Logan A. Development and validation of transfusion risk understanding scoring tool (TRUST) to stratify cardiac surgery patients according to their blood transfusion needs. Transfusion. 2006;46:1120-9.

13. Vanneman MW, Dalia AA. TRACKing down perioperative transfusion in cardiac surgery. J Cardiothorac Vasc Anesth. 2019;33:2676-8.
14. Mazer CD, Whitlock RP, Fergusson DA, Hall J, Belley-Cote E, Connolly K, et al. Restrictive or liberal red-cell transfusion for cardiac surgery. N Engl J Med. 2017; 377:2133-44.

15. Gillissen A, van den Akker T, Caram-Deelder C, Henriquez DDCA, Nij Bijvank SWA, Bloemenkamp KWM, et al. Predictive value of a bleeding score for postpartum hemorrhage. Res Pract Thromb Haemost. 2019;3:277-84.

16. Mahla E, Tantry US, Prüller F, Gurbel PA. Is there a role for preoperative platelet function testing in patients undergoing cardiac surgery during antiplatelet therapy? Circulation. 2018;138:2145-59.

17. Nakashima CAK, Dallan LAO, Lisboa LAF, Hajjar LA, Soeirp AM, Silva BA, et al. Platelet aggregability evaluation in patients with acute coronary syndromes scheduled for coronary artery bypass graft. The PLAT-CABG study. Eur Heart J. 2019;40(Suppl 1).

18. Saraf S, Bensalha I, Gorog DA. Antiplatelet resistance-does it exist and how to measure it? Clin Med Cardiol. 2009;2009:77-91.

19. Payne DA, Hayes PD, Jones CI, Belham P, Naylor AR, Goodall AH. Combined therapy with clopidogrel and aspirin significantly increases the bleeding time through a synergistic antiplatelet action. J Vasc Surg. 2002;35: 1204-9.

20. Mehta SR, Bainey KR, Cantor WJ, Lordkipanidzé M, Marquis-Gravel G, Robinson SD, et al. 2018 Canadian Cardiovascular Society/Canadian Association of Interventional Cardiology focused update of the guidelines for the use of antiplatelet therapy. Can J Cardiol. 2018;34:214-33.

21. Jiang X-L, Samant S, Lesko LJ, Schmidt S. Clinical Pharmacokinetics and Pharmacodynamics of Clopidogrel. Clin Pharmacokinet. 2015;54:147-66.

\section{Commentary: Shall we wait for two days more? Can we take this risk?}

\author{
Stefano D'Alessandro, MD, FECTS, ${ }^{a}$ \\ Fabio Guarracino, MD, \\ Francesco Nicolini, $\mathrm{MD}, \mathrm{PhD},{ }^{\mathrm{c}}$ and \\ Francesco Formica, $\mathrm{MD}^{\mathrm{c}}$
}

Dual antiplatelet therapy (DAPT) with P2Y12-receptor inhibitors and aspirin is a well-recognized treatment aiming

From ${ }^{a}$ Cardiac Surgery Unit, Cardiac-Thoracic-Vascular Department, San Gerardo Hospital, Monza; ${ }^{b}$ Department of Anaesthesia and Critical Care Medicine, Cardiothoracic and Vascular Anaesthesia and Intensive Care, University Hospital, Pisa; and ${ }^{\mathrm{C}}$ Cardiac Surgery Unit, Department of Medicine and Surgery, Parma General Hospital, University of Parma, Parma, Italy.

Disclosures: The authors reported no conflicts of interest.

The Journal policy requires editors and reviewers to disclose conflicts of interest and to decline handling or reviewing manuscripts for which they may have a conflict of interest. The editors and reviewers of this article have no conflicts of interest.

Received for publication April 20, 2020; accepted for publication April 21, 2020; available ahead of print May 1, 2020.

Address for reprints: Francesco Formica, MD, UOC Cardiochirurgia, Azienda Ospedaliera Universitaria di Parma, Via A. Gramsci, 14, 43126 Parma, Italy (E-mail: francesco_formica@fastwebnet.it or francesco.formica@unipr.it).

J Thorac Cardiovasc Surg 2022;163:1056-7

$0022-5223 / \$ 36.00$

Copyright (c) 2020 by The American Association for Thoracic Surgery

https://doi.org/10.1016/j.jtcvs.2020.04.076

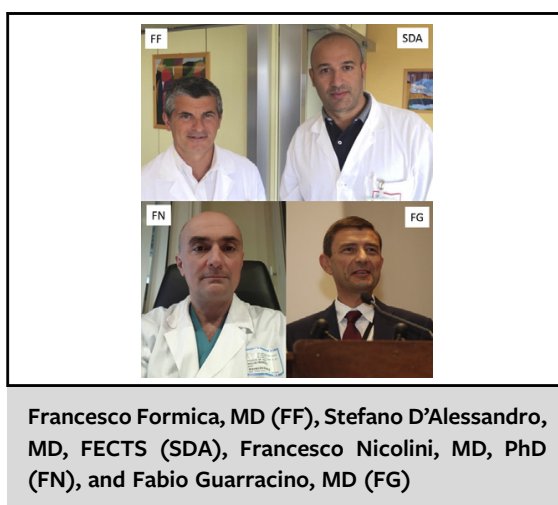

CENTRAL MESSAGE

In patients with acute coronary

syndrome, mainly in subjects

younger than 65 years, waiting

for 2 more days before stopping

DAPT might be reasonable to

reduce the risk of major bleeding

complications.

to reduce the incidence and recurrence of ischemic and thrombotic complications in coronary patients suffering from acute myocardial infarction and in patients who 
undergo percutaneous coronary intervention (PCI). Recent guidelines have well defined both the use of DAPT with P2Y12-receptor inhibitors such as clopidogrel and the more recent prasugrel and ticagrelor. ${ }^{1,2}$ Nevertheless, the association between antiplatelets agents and perioperative bleeding risk has not adequately addressed, and the literature shows conflicting evidence. Moreover, different bleeding classifications $\mathrm{s}^{3-7}$ have limited the standardization of the bleeding definition.

On this topic, Qu and colleagues ${ }^{8}$ investigated the benefits and complications associated with early discontinuation of DAPT before surgery for patients with acute coronary syndrome. The authors observed a significant increase in 30-day composite outcome, stroke, major bleeding, reoperation for bleeding, and transfusions in patients in whom clopidogrel was stopped before 5 days compared with patients who had the therapy discontinued after 5 days. Although the results reported by the authors confirm the previously highlighted evidence, they deserve to be congratulated for having conducted their single-center observational study with a large sample of patients and an impressive statistical methodology.

The authors have reported outcomes in 3 subgroups based on the discontinuation days of clopidogrel: $<3$ days, 3-5 days, and $>5$ days. In patients who stopped clopidogrel $<3$ days, 30-day composite outcome, stroke, major bleeding, reoperation for bleeding, and transfusions were clearly more represented than in the other 2 subgroups. When the analysis was restricted to 3-5 days' subgroup, only bleeding complications and stroke had a greater incidence compared with patients in $>5$ days subgroup.

Stroke might be directly correlated to an increase in the rate of transfusions as a results of major bleeding. ${ }^{9,10}$ Hence, the following question may arise: in stable patients who had the clopidogrel therapy discontinuation between 3 and 5 days, was it safe and reasonable waiting for further 2 days to reduce the risk of major bleeding complications? After considering the data from $\mathrm{Qu}$ and colleagues, ${ }^{8}$ who described the same incidence of death and myocardial infarction between the 2 subgroups, it might be reasonable waiting for $>5$ days to strongly reduce bleeding complications, according to the patient's clinical status. The same question should be asked for patients younger than 65 years.
In these subjects, as stated by the authors, withdraw of clopidogrel before 5 days might be clinically feasible without an increasing risk of cardiac and cerebrovascular events, but with an increasing risk of bleeding events. Hence, waiting for a further few days might be considered to reduce the risks of bleeding and transfusions.

The introduction of P2Y12-receptor inhibitors provided interventional cardiologists with an effective therapy to reduce the risk of early and late thrombotic events following PCI procedures. Surgeons have to assess the right balance between thrombotic and postoperative major bleeding events by using ad hoc bleeding scores, especially in high-risk patients (primary PCI, obesity, older age, thrombocytopenia, anemia). Probably in this scenario, waiting for 2 more days might be a reasonable practice.

\section{References}

1. Pagano D, Milojevic M, Meesters MI, Benedetto U, Bolliger D, von Heyemann C, et al. 2017 EACTS/EACTA guidelines on patient blood management for adult cardiac surgery. Eur J Cardiothorac Surg. 2018;43:79-111.

2. Sousa-Uva M, Head SJ, Milojevic M, Collet JP, Landoni G, Castella M, et al. 2017 EACTS guidelines on perioperative medication in adult cardiac surgery. Eur J Cardiothorac Surg. 2018;53:5-33.

3. Kinnunen EM, De Feo M, Reichart D, Tauriainen T, Gatti G, Onorati F, et al. Incidence and prognostic impact of bleeding and transfusion after coronary surgery in low-risk patients. Transfusion. 2017;57:178-86.

4. Biancari F, Ruggieri VG, Perrotti A, Svenarud P, Dalén P, Onorati F, et al. European multicenter study on coronary artery bypass grafting (E-CABG registry): study protocol for a prospective clinical registry and proposal of classification of postoperative complications. J Cardiothorac Surg. 2015;10:90.

5. Dyke C, Aronson S, Dietrich W, Hofmann A, Karkouti K, Levi M, et al. Universal definition of perioperative bleeding in adult cardiac surgery. J Thorac Cardiovasc Surg. 2014;147:1458-63.

6. Kinnunen EM, Juvonen T, Airaksinen KE, Heikkinen J, Kettunen U, Mariscalco G, et al. Clinical significance and determinants of the universal definition of perioperative bleeding classification in patients undergoing coronary artery bypass surgery. J Thorac Cardiovasc Surg. 2014; 148:1640-6.

7. Vranckx P, White HD, Huang Z, Mahaffey KW, Armstrong PW, Van de Werf F, et al. Validation of BARC bleeding criteria in patients with acute coronary syndromes: the TRACER trial. J Am Coll Cardiol. 2016;67:2135-44.

8. Qu J, Zhang D, Zhang H, Rao C, Chen S, Zhao Y, et al. Preoperative clopidogrel and outcomes in patients with acute coronary syndrome undergoing coronary artery bypass surgery. J Thorac Cardiovasc Surg. 2022;163:1044-52.e15.

9. Mikkola R, Gunn J, Heikkinen J, Wistbacka JA, Teittinen K, Kuttila K, et al. Use of blood products and risk of stroke after coronary artery bypass surgery. Blood Transfus. 2012;10:490-501.

10. Ranucci M, Aronson S, Dietrich W, Dyke CM, Hofmann A, Karkouti K, et al Patient blood management during cardiac surgery: do we have enough evidence for clinical practice? J Thorac Cardiovasc Surg. 2011;142: 249.e1-38. 